\title{
A Geotechnical and Geochemical Characterisation of Oil Fire Contaminated Soils in Kuwait
}

\author{
Humoud Al-Dahanii ${ }^{1}$, Paul Watson ${ }^{1}$ and David Giles ${ }^{2}$ \\ ${ }^{1}$ School of Civil Engineering and Surveying, ${ }^{2}$ School of Earth and Environmental Sciences, \\ University of Portsmouth, UK.
}

As a consequence of the Saddam Hussein 1991 Iraqi led invasion of Kuwait more than 600 oil wells were set fire to as part of a scorched earth policy while retreating from the country. This action created a series of "oil lakes" and hydrocarbon contamination within the desert causing serious environmental damage. Some 23 years later after the fires were extinguished the ground affects of these actions can still be detected. This paper will present the results of a detailed geotechnical and geochemical investigation into the current ground conditions now present in the Burgan Oil Field some $35 \mathrm{~km}$ south of Kuwait City. Detailed geotechnical testing together with hydrocarbon analysis using a Gas Chromatograph - Mass Spectrometer (GCMS) have been carried out on samples from varying depths within the Greater Burgan Oil Field. A detailed geological, geotechnical and geochemical ground model has been developed to present the findings of these investigations. The area under study has major development plans for both housing and infrastructure. Subsequent Quantitative Human Health Risk Assessments have been undertaken to determine the potential levels of risk posed to any future urban developments within these affected areas. The paper will report on this assessment detailing the hazards posed and the tools used to assess them. Potential risks will be discussed and mitigation and management scenarios will be highlighted.

Keywords Oil lakes, hydrocarbon contamination, risk assessment, geotechnical assessment.

\section{Introduction}

The state of Kuwait has experienced serious environmental damage as a consequence of the formation of multiple oil lakes and hydrocarbon contamination resulting from the destruction caused in the Gulf War of 1991. Of the 810 active oils wells operating in Kuwait in 1991, 730 were damaged or set ablaze during the conflict (Fig. 1). This research set out to assess the hydrocarbon contamination 
and geotechnical effects of the oil fires still being encountered some 20 years plus after the war.

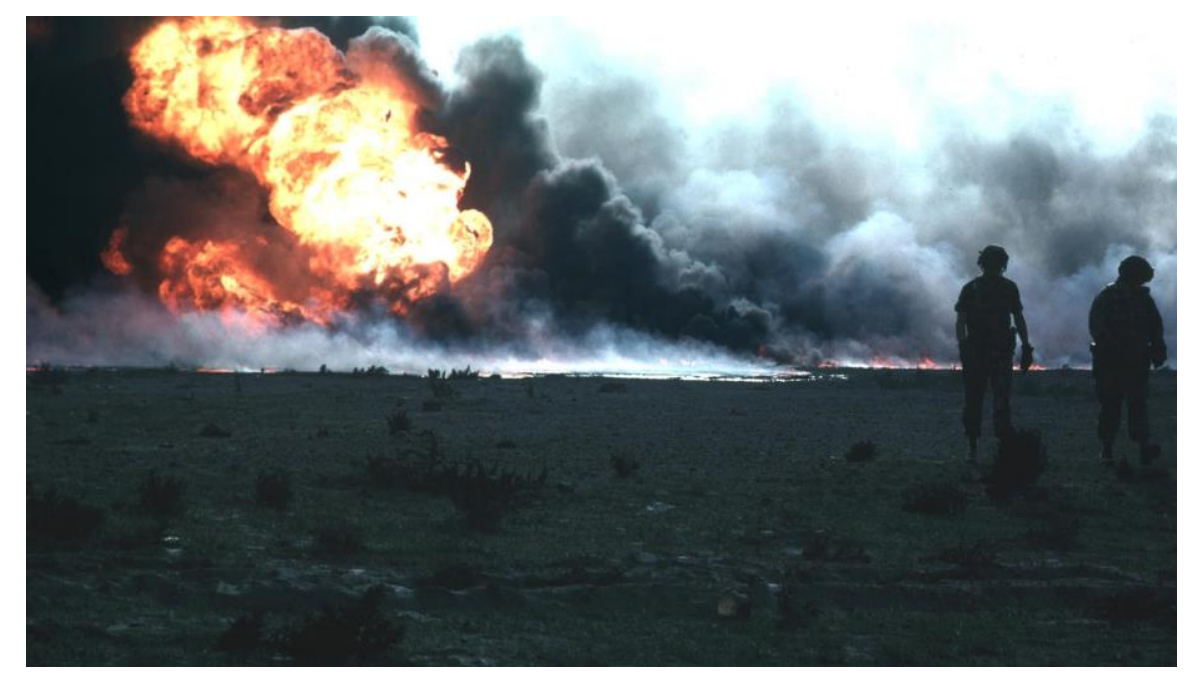

Fig. 1 Burning oilfield during Operation Desert Storm, Kuwait (USACE).

\section{Site Description}

The area under study was located in the Greater Burgan oilfield (Fig. 2) which lies in the Arabian Basin. The Greater Burgan field is the largest clastic oil field in the world covering an area of $838 \mathrm{~km}^{2}$, located in south eastern Kuwait. The oil field is subdivided into the Burgan, Magwa and Ahmadi sectors based on the underlying geological structure (Kaufman et al, 2000). At the height of the destruction smoke plumes from the Greater Burgan oil fires extended over $50 \mathrm{~km}$ from the well sites up to an altitude of $2.5 \mathrm{~km}$. Spillages from ruptured pipelines resulted in numerous oil lakes which caused extensive contamination and environmental damage.

\section{Site Geology}

Kuwait is dominated by rocks of Tertiary age dating from the Palaeocene to the Eocene (Al-Sulaimi and Mukhopadhyay, 2000). Limestones, dolomites and evaporitic sequences (anhydrites) from the Umm Er Radhuma, Rus and Dammam Formations are unconformably overlain by sandstones of the Kuwait Group which include the Fars and Ghar Formations, again overlain by the Dibdibba Formation. 
The solid geology of the Greater Burgan site is located within the Fars and Ghar Formations with interbedded sands and clays, some sandstones and weak white nodular limestones (Hunting Surveys, 1981). Superficial deposits are predominantly Aeolian sands, with occasional gravels with sands, muds and calcareous sandstones in the coastal areas. (Table 1).

The Greater Burgan oil fields main producing reservoirs are within the Cretaceous Burgan, Mauddud and Wara Formations, all sandstones.

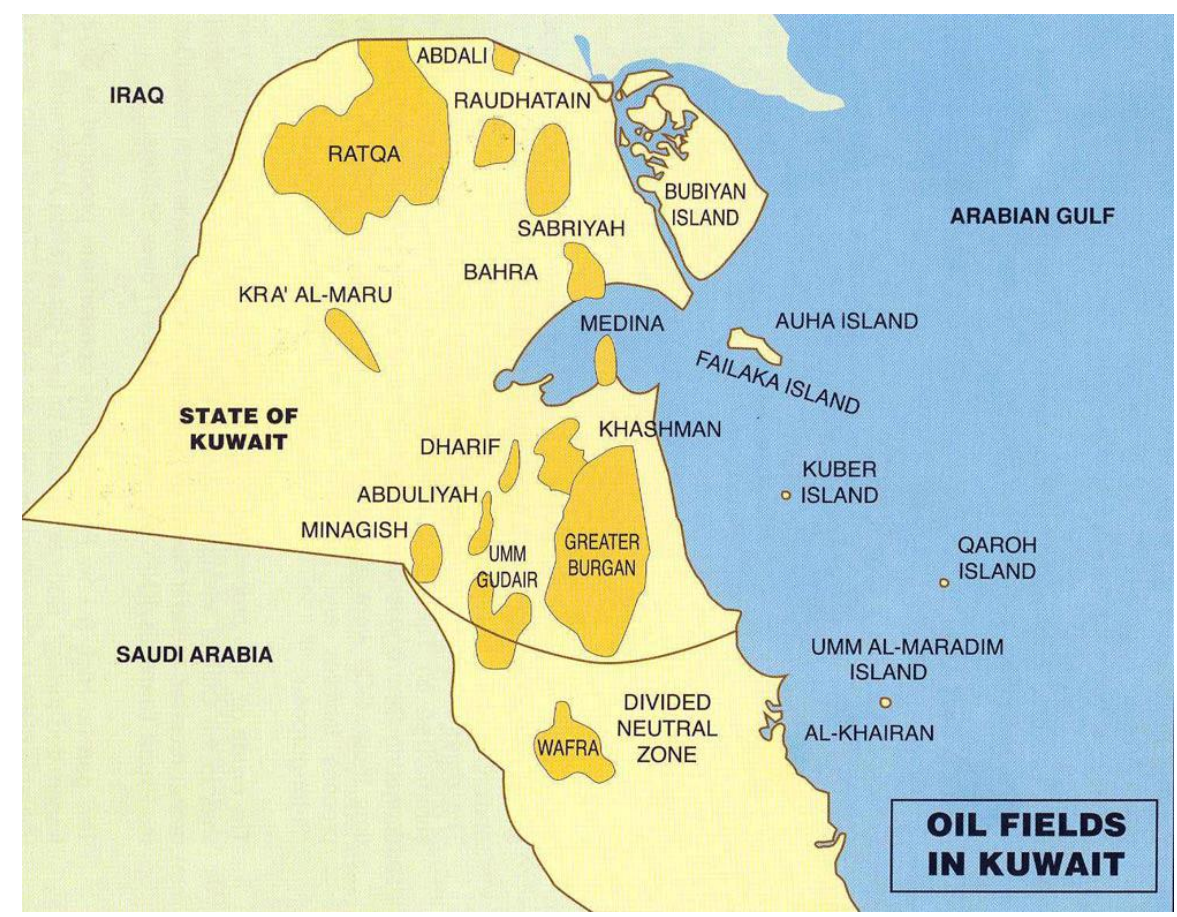

Fig. 2 Oil fields in Kuwait (Kuwait Oil Company KOC).

\section{Investigation and Testing}

A significant number of ground investigation boreholes were commissioned to determine the site specific geology and to collect samples for both geotechnical and geochemical characterization. The Burgan and Magwa sectors were chosen for this more detailed investigation. Both near surface (ground level), shallow (up to $2 \mathrm{~m}$ ) and deep (up to $6 \mathrm{~m}$ ) samples were taken to determine the critical zones for hosting potential contamination or problematic ground conditions. Standard in-situ 
and laboratory geotechnical tests were undertaken including Standard Penetration Tests, particle size distribution analysis, Atterberg Limits and Direct Shear tests where applicable. Chemical testing was primarily performed using Gas Chromatograph Mass Spectrometry (GCMS) to ascertain the nature of the residue hydrocarbons present together with elemental analysis. Water soluble chlorides and water soluble sulphates were also tested for (Table 2). The GCMS enabled the speciation of the hydrocarbons present in order to determine the degradation that had taken place since the original spillages in 1991 (Fig. 4).

Table 1. Generalised stratigraphy of the study area.

\begin{tabular}{|c|c|c|c|}
\hline \multicolumn{3}{|c|}{ GENERALISED STRATIGRAPHY } & $\begin{array}{l}\text { HYDRO } \\
\text { GEOLOGICAL } \\
\text { UNITS } \\
\end{array}$ \\
\hline \multicolumn{2}{|c|}{$\begin{array}{l}\text { QUATERNARY SEDIMENTS } \\
\quad(<30 \mathrm{~m})\end{array}$} & $\begin{array}{l}\text { Unconsolidated sands and gravels, gyp- } \\
\text { siferous and calcareous silts and clays }\end{array}$ & $\begin{array}{l}\text { Localised } \\
\text { Aquifers }\end{array}$ \\
\hline \multirow[t]{3}{*}{$\begin{array}{l}\text { KUWAIT } \\
\text { GROUP }\end{array}$} & $\begin{array}{l}\text { DIBDIBBA } \\
\text { FORMATION } \\
(200-200 \mathrm{~m})\end{array}$ & \multirow[t]{2}{*}{$\begin{array}{l}\text { Gravelly sand, sandy gravel, calcareous } \\
\text { and gypsiferous sand, calcareous silty } \\
\text { sandstone, sandy limestone, marl and } \\
\text { shale, locally cherty }\end{array}$} & \multirow[t]{2}{*}{ Aquifer } \\
\hline & \multirow[t]{2}{*}{$\begin{array}{l}\text { FARS \& GHAR } \\
\text { FORMATIONS }\end{array}$} & & \\
\hline & & $\begin{array}{l}\text { Localised shale, clay and calcareous } \\
\text { silty sandstone }\end{array}$ & Aquitard \\
\hline \multirow[t]{5}{*}{$\begin{array}{l}\text { HASA } \\
\text { GROUP }\end{array}$} & \multirow[t]{2}{*}{$\begin{array}{l}\text { DAMMAM } \\
\text { FORMATION } \\
(60-200 \mathrm{~m})\end{array}$} & $\begin{array}{l}\text { Chalky, marly, Dolomitic and calcare- } \\
\text { nitic limestone }\end{array}$ & Aquifer \\
\hline & & $\begin{array}{l}\text { Nummulitic limestone with lignites and } \\
\text { shales }\end{array}$ & $\begin{array}{l}\text { Aquitard } \\
\text { locally }\end{array}$ \\
\hline & $\begin{array}{l}\text { RUS } \\
\text { FORMATION } \\
(20-200 \mathrm{~m}) \\
\end{array}$ & Anhydrite and limestone & Aquiclude \\
\hline & $\begin{array}{l}\text { UMM ER } \\
\text { RADHUMA } \\
\text { FORMATION } \\
(300-600 \mathrm{~m})\end{array}$ & $\begin{array}{l}\text { Limestone and dolomite (calcarenitic in } \\
\text { the middle) with localised anhydrite lay- } \\
\text { ers }\end{array}$ & Aquifer \\
\hline & \multirow[t]{2}{*}{ Disconformity } & Shales and marls & Aquitard \\
\hline $\begin{array}{l}\text { ARUMA } \\
\text { GROUP }\end{array}$ & & Limestone and shaly limestone & Aquifer \\
\hline
\end{tabular}




\section{Contamination Modeling}

Currently a human health exposure assessment utilizing the ground investigation and laboratory test results is being undertaken using the RISC (Risk Integrated Software for Cleanups) software tool for performing human health risk assessments for hydrocarbon contaminated sites using fate and transport models to estimate receptor point concentrations in indoor and outdoor air and groundwater (ESI, n.d.). The sites being assessed are potential future housing developments associated with the expansion of the city of Al Ahmadi. Both airborne and ingestions pathways are being assessed for a variety of receptors.

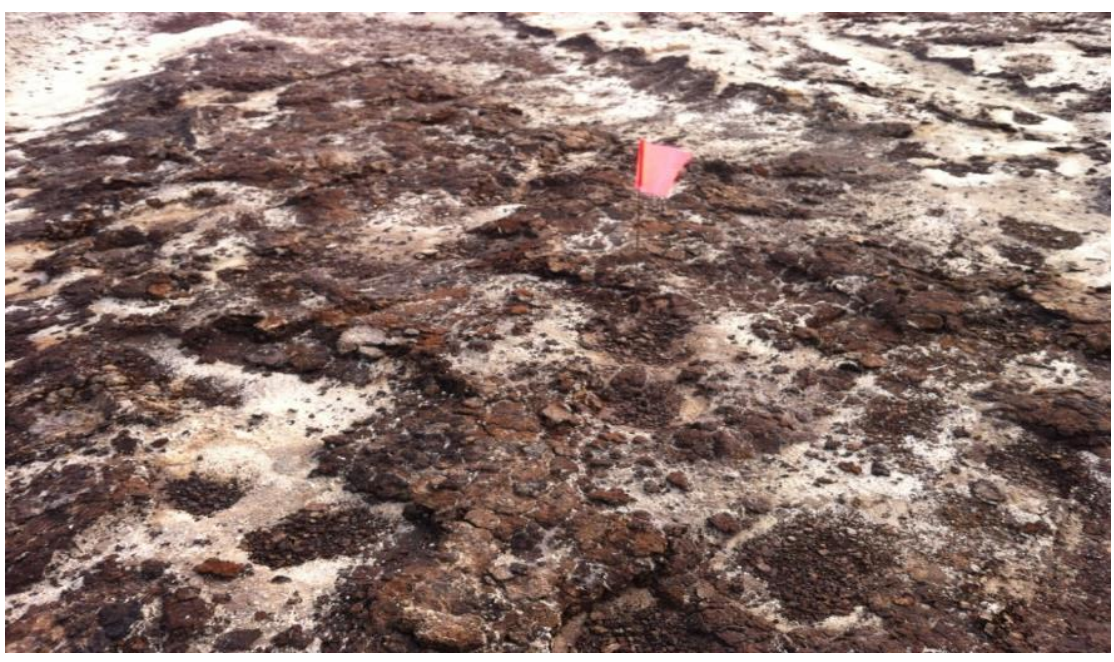

Fig 3. Typical site profile showing degraded hydrocarbon contamination.

Table 2. Example chemical results from Greater Burgan Field-al Magwa.

\begin{tabular}{|c|c|c|c|c|c|c|c|c|c|}
\hline \multirow{3}{*}{ S.I } & \multirow{3}{*}{ T.P.No. } & \multirow{3}{*}{$\begin{array}{c}\text { Depth } \\
\text { of } \\
\text { Sample } \\
\text { (m) }\end{array}$} & \multicolumn{2}{|c|}{$\begin{array}{l}\text { Water Soluble } \\
\text { Chloride }\left(\mathrm{Cl}^{-}\right) \\
\end{array}$} & \multicolumn{4}{|c|}{ Water Soluble Sulfate } & \multirow{3}{*}{ pH } \\
\hline & & & & & as $\mathrm{SO}_{3}$ & & as $\mathrm{SO}_{4}$ & & \\
\hline & & & $\%$ & PPM & $\%$ & PPM & $\%$ & PPM & \\
\hline 1 & \multirow{6}{*}{ ڤ્छ } & 0.00 & 0.0425 & 425 & 0.1240 & 1240 & 0.1488 & 1488 & 7.84 \\
\hline 2 & & 0.25 & 0.0283 & 283 & 0.0919 & 919 & 0.1103 & 1103 & 8.94 \\
\hline 3 & & 0.50 & 0.0567 & 567 & 0.0746 & 746 & 0.0895 & 895 & 8.61 \\
\hline 4 & & 1.00 & 0.1645 & 1645 & 0.0304 & 304 & 0.0365 & 365 & 7.83 \\
\hline 5 & & 1.50 & 0.0822 & 822 & 0.0902 & 902 & 0.1082 & 1082 & 8.29 \\
\hline 6 & & 2.00 & 0.0567 & 567 & 0.0554 & 554 & 0.0665 & 665 & 8.36 \\
\hline
\end{tabular}




\section{Summary}

The legacy of the Saddam Hussein 1991 invasion of Kuwait and the subsequent destruction of the oil producing facilities is still detectable in the geotechnical and geochemical soil profile. Human Health Risk Assessments are being undertaken and contamination remediation strategies designed to enable future developments on or near these sites. Elevated Total Petroleum Hydrocarbons (TPH) levels have been detected as expected and their potential impact is currently being evaluated.

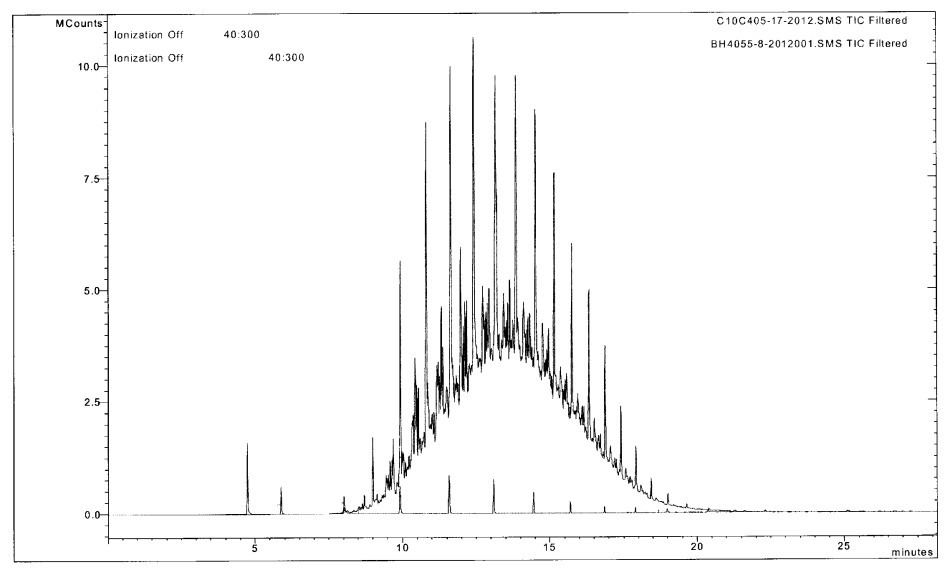

Fig 4. Gas Chromatogram of hydrocarbon contaminated soil from Abdally sector.

\section{References}

Al-Sulaimi, J., \& Mukhopadhyay, A. (2000). An overview of the surface and nearsurface geology, geomorphology and natural resources of Kuwait. Earth-Science Reviews, 50(3), 227-267. 10.1016/S0012-8252(00)00005-2

ESI (n.d.) RISC - Integrated Software for Cleanups. Retrieved from http://esinternational.com/risc/

Hunting Geology \& Geophysics (1981). Photographic survey of the State of Kuwait. Submitted to the Kuwait Oil Company, Kuwait.

Kaufman, R. L., Kabir, C. S., Abdul-Rahman, B., Quttainah, R., Dashti, H., Pederson, J. M., \& Moon, M. S. (2000). Characterizing the Greater Burgan field with geochemical and other field data. SPE Reservoir Evaluation \& Engineering, 3(2), 118-126. 10.2118/62516-PA 